Etihad: Journal of Islamic Banking and Finance

Vol. 1, No. 1, Januari - Juni 2021: 66-81

\title{
PENILAIAN KINERJA BANK MEGA SYARIAH DENGAN METODE BALANCED SCORECARD PERIODE 2015-2019
}

\author{
Wahyuni Aminatun ${ }^{1}$, Parno ${ }^{2}$, Angrum Pratiwi ${ }^{3}$ \\ 1,2,3 UIN Sultan Aji Muhammad Idris Samarinda, Indonesia \\ Email:mwahyuni.aminatun@gmail.com,agt122005@gmail.com, \\ angrumpratiwi89@gmail.com
}

\begin{abstract}
The purpose of this study was to determine the performance assessment of Bank Mega Syariah with the Balanced Scorecard method. There are four aspects of assessment in the balanced scorecard, namely financial perspective, customer perspective, internal business process perspective, and learning and growth perspective. The research method used is descriptive quantitative. The type of data is secondary, sourced from the Financial Statements and Annual Reports that have been published by Bank Mega Syariah. The data collection technique uses the documentation method from the official website of the Financial Services Authority, and the official website of Bank Mega Syariah. Data analysis technique is to calculate the score of each perspective, based on predetermined criteria. The results obtained from the analysis of the performance assessment of Bank Mega Syariah using the Balanced Scorecard method for the 2015-2019 period, for a financial perspective the NPF ratio shows a healthy predicate, the FDR ratio with a fairly healthy predicate, and an ROA ratio with a healthy predicate. healthy predicate, ROE ratio with fairly healthy predicate, BOPO ratio with very healthy predicate, and CAR ratio with very healthy predicate. For the customer perspective, it shows a decrease in Market Share and shows an increase in Customer Profitability. For the internal business process perspective, it shows an increase in Process Innovation and an increase in After Sales Service. For the learning and growth perspective, it shows a decrease in employee retention and shows an increase in employee productivity.
\end{abstract}

Keywords: balanced scorecrad, financial perspective, customer perspective, internal business process perspective, learning and growth perspective.

Abstrak: Tujuan penelitian ini adalah mengetahui penilaian kinerja Bank Mega Syariah dengan metode Balanced Scorecard. Terdapat empat aspek penilaian dalam balanced scorecard, yaitu perspektif keuangan, perspektif pelanggan, perspektif proses bisnis internal, dan perspektif pembelajaran dan pertumbuhan. Metode penelitian yang digunakan adalah kuantitatif deskriptif. Jenis data yaitu sekunder, yang bersumber dari Laporan Keuangan dan Laporan Tahunan yang telah dipublikasi oleh Bank Mega Syariah. Teknik pengumpulan data menggunakan metode dokumentasi dari website resmi Otoritas Jasa Keuangan, dan website resmi Bank Mega Syariah. Teknik analisis data yaitu dengan menghitung skor masing-masing perspektif, berdasarkan kriteria yang telah ditetapkan. Hasil yang diperoleh dari kajian analisis penilaian kinerja Bank Mega Syariah dengan menggunakan metode Balanced Scorecard periode 2015-2019, untuk perspektif keuangan pada rasio NPF menunjukkan predikat sehat, 
rasio FDR dengan predikat cukup sehat, rasio ROA dengan predikat sehat. predikat sehat, rasio ROE dengan predikat cukup sehat, rasio BOPO dengan predikat sangat sehat, dan rasio CAR dengan predikat sangat sehat. Untuk perspektif pelanggan menunjukkan penurunan Pangsa Pasar dan menunjukkan peningkatan Profitabilitas Pelanggan. Untuk perspektif proses bisnis internal menunjukkan peningkatan dalam Inovasi Proses dan peningkatan Layanan Purna Jual. Untuk perspektif pembelajaran dan pertumbuhan menunjukkan penurunan Retensi Karyawan dan menunjukkan peningkatan Produktivitas Karyawan.

Kata Kunci: balanced scorecrad, perspektif keuangan, perspektif pelanggan, perspektif proses bisnis internal, perspektif pembelajaran dan pertumbuhan.

\section{PENDAHULUAN}

Seiring dengan laju perkembangan teknologi, khususnya teknologi informasi, dunia bisnis mau tidak mau telah mengalami perubahan yaitu dari era persaingan industri menuju era persaingan informasi. Perusahaan harus dapat beradaptasi dengan lingkungan bisnis global yang senantiasa berubah dan mampu bersaing dalam pasar internasional. Untuk memenangkan persaingan yang semakin kompetitif ini, diperlukan sebuah strategi baru yang dalam pelaksanaannya membutuhkan suatu pengukuran kinerja, yang berguna untuk menilai berhasil tidaknya strategi baru tersebut (Hery, 2017). Dalam pemikiran masyarakat, perusahaan yang pencapaian keuanganya tinggi dianggap sebagai perusahaan yang berhasil. Padahal dalam mengukur kinerja perusahaan tidak bisa dilihat hanya dari sisi keuangan tetapi juga non keuangan. Metode yang digunakan jasa keuangan untuk menjaga kesetiaan konsumen salah satunya dengan balanced scorecard (BSC). Dimana, perusahaan jasa keuangan akan lebih mampu dalam meramalkan dan merencakan perbaikan terhadap kesetiaan dan mempertahankan konsumen (Hery, 2017).

Balanced Scorecrad (BSC) merupakan suatu konsep manajemen kontemporer yang dapat digunakan sebagai alat untuk menilai kinerja yang dilakukan dengan komprehensif, terukur dan berimbang (Kaplan \& Norton, 2005). Sehingga kemudian para eksekutif perbankan syariah sekarang dapat mengukur seberapa besar unit bisnis mereka menciptakan nilai bagi para nasabah dan seberapa jauh manajemen harus meningkatkan kapabilitas internal dan investasi di dalam sumber daya manusia (Putri \& Hasanah, 2014).

Balanced Scorecard merupakan salah satu model pengukuran kinerja yang dikembangkan oleh Kaplan (1992), kemudian dikembangkan oleh Norton pada 1996. Balanced scorecard ini merupakan kerangka agar organisasi dapat melaksanakan program-program yang memfokuskan pada strategi yang disusun oleh organisasi tersebut (Kaplan \& Norton, 2007). Pengukuran kinerja menggunkan balanced sccorecard memiliki pandangan terhadap pengukuran kinerja pada empat perspektif, yaitu perspektif keuangan, perspektif pelanggan, perspektif internal, dan perspektif pembelajaran dan pertumbuhan. Dengan balanced scorecard, akan membantu manajer atau bahkan suatu organisasi itu sendiri untuk memfokuskan pada ukuran kinerja agar menyeimbangkan di antara keempat perspektif yang telah disebutkan (Koesomowidjojo, 2017). 
Sektor perbankan dipilih oleh peneliti karena industri perbankan sebuah perusahaan profit oriented yang berpegang pada regulasi yang berlaku dalam suatu negara. Oleh karena itu, diperlukan suatu pengukuran kinerja yang berimbang seperti balance scorecard. Bank Mega Syariah merupakan salah satu Bank Umum Syariah (BUS) di Indonesia yang sudah berdiri sejak tahun 2010, banyak prestasi yang diraih Bank Mega Syariah dari segi keuangan dan non keuangan. Sepanjang tahun 2016, Bank Mega Syariah berhasil memperoleh penghargaan dan sertifikasi sebagai "Best Banking Brand 2016 for Best Reputation Title" (Bank Mega Syariah, 2016). Pada tahun 2017 mendapat penghargaan dari Indonesia Sharia Finance Award 2017 yaitu "Special Mention Promoting Financial Literacy" (Bank Mega Syariah, 2017). Penghargaan yang diperoleh Bank Mega Syariah tahun 2018 yaitu Bank berkinerja terbaik untuk Kategori Bank Umum Syariah pada "Bisnis Indonesia Financial Award (BIFA) 2018" yang diselenggarakan Harian Bisnis Indonesia. Peringkat Kedua Kategori Bank Syariah pada "Indonesia Enterprise Risk Management Award" yang diselenggarakan oleh Economic Review, dan "The Best Productivity Bank" pada "Indonesia Banking Award (IBA) 2018" yang diselenggarakan Tempo (Bank Mega Syariah, 2018). Pada tahun 2019 Bank Mega Syariah (BMS) mendapatkan Penghargaan dari Economic Review dalam Indonesia Good Corporate Governance Awards 2019 (Bank Mega Syariah, 2019a).

Penelitian yang dilakukan oleh Puspasari dan Eviana (2015), melakukan penelitian mengukur kinerja perusahaan penyedia jasa keuangan dengan menggunakan pendekatan Balanced Scorecard studi kasus pada PT. BPRS Artha Pamenang. Hasil penelitian disimpulkan bahwa kinerja PT. BPRS Artha Pamenang selama periode 2015 adalah baik. Tetapi perlu diperhatikan bahwa terdapat beberapa indikator yang memerlukan peningkatan dan perbaikan untuk meningkatkan kinerja perusahaan pada periode berikutnya (Puspasari \& Eviana, 2015). Penelitian oleh Marselia., dkk (2017) dengan judul "Pengukuran Kinerja Perusahaan Menggunakan Metode Balanced Scorecard di PDAM Tirta Al-Bantani Kabupaten Serang". Kesimpulan dari penelitian ini adalah pengukuran kinerja secara keseluruhan dengan metode Balanced Scorecard dari empat perspektif sebesar 3,791 menunjukkan kinerja perusahaan dikategorikan kondisi cukup baik (Marselia et al., 2017).

Penelitian yang dilakukan Arwinda \& Sari (2015), melakukan penelitian analisis balanced scorecard sebagai alat pengukuran kinerja perusahaan PT. Jamsostek Cabang Belawan. Hasil menunjukkan perhitungan balanced scorecard (BSC) diketahui bahwa kinerja PT. Jamsostek Cabang Belawan masih dikatakan kurang baik, kinerja masih perlu diperbaiki lagi agar perusahaan mampu mencapai kinerja sangat baik (Arwinda \& Sari, 2015). Penelitian yang dilakukan Pratiwi (2015), tentang perbandingan kinerja BPRS dengan Pendekatan Balanced Scorecard di Yogyakarta. Hasil uji beda menunjukkan bahwa kinerja perspektif konsumen, perspektif bisnis internal, serta perspektif pembelajaran dan pertumbuhan kedua BPRS tidak mempunyai perbedaan. Namun, hasil uji beda prespektif keuangan menunjukkan perbedaan antara keduanya. Meskipun demikian, hasil kuesioner menunjukkan BPRS Barokah Dana Sejahtera terlihat lebih unggul pada prespektif pertumbuhan dan pembelajaran karena adanya team work yang solid (Pratiwi, 2015). Berdasarkan penelitian yang sudah dilakukan oleh para 
peneliti terdahulu, ada beberapa perbedaan antara lain periode penelitiannya hanya menggunakan tahun 2015 sebagai tolok ukur, sedangkan penelitian ini selama tahun 2015 hingga 2019. Perusahaan yang digunakan adalah perusahaan umum dan Bank Pembiayaan Rakyat Syariah, belum banyak melakukan penelitian khususnya di Bank Umum Syariah.

Berdasarkan teori diatas, adanya alternatif pengukuran kinerja keuangan perusahaan dan beberapa research gap diatas, maka perlu melakukan penelitian pada salah satu Bank Umum Syariah dan mengangkat judul "Penilaian Kinerja Bank Mega Syariah dengan Metode Balanced Scorecard Tahun 2015-2019". Tujuan penelitian ini adalah mengetahui dan menganalisa kinerja Bank Mega Syariah dengan metode Balanced Scorecard pada empat (4) aspek yaitu aspek keuangan, aspek pelanggan, aspek bisnis internal, serta aspek pertumbuhan dan pembelajaran.

\section{TINJAUAN LITERATUR}

Penilaian kinerja suatu bank atau unit kerja termasuk cabang biasaya diukur dengan aspek kuantitatif dan kualitatif merujuk pada target kinerja yang biasa disebut Key Performance Indicator (KPI). Kinerja kuantitatif secara konsolidasi dapat dilihat dari laporan keuangan, sementara secara kualitatif dapat dilakukan pendekatan penilaian tingkat kesehatan bank sebagaimana ditetapkan oleh Otoritas Jasa Keuangan (OJK). Kinerja suatu bank atau cabang tersebut diukur dengan cara membandingkannya dengan periode sebelumnya, proyeksi keuangan, atau terhadap benchmark dengan bank lainnya (Ikatan Bankir Indonesia, 2014).

Balanced Scorecard terdiri dari dua kata, yaitu balanced yang secara harfiah berarti seimbang, dan scorecard yang berarti kartu skor. Scorecard adalah kartu yang digunakan untuk mencatat skor hasil kinerja seseorang/kelompok. Melalui kartu skor, seseorang/kelompok akan dievaluasi kinerjanya dengan membandingkan antara apa yang telah dikerjakan dengan apa yang telah direncanakan (Yuwono et al., 2002). Sedangkan balanced menggambarkan bahwa kinerja seseorang/kelompok akan diukur secara berimbang, yaitu dari aspek keuangan dan non keuangan, sisi internal dan eksternal, perspektif orang dan proses, jangka pendek dan jangka panjang (Hery, 2017).

Balanced Scorecard adalah kumpulan ukuran kinerja yang terintegrasi yang diturunkan dari misi dan visi perusahaan untuk mendukung strategi perusahaan secara keseluruhan. Balanced Scorecard System meliputi ukuran keuangan dan non keuangan, yang terdiri atas keuangan, konsumen, bisnis internal, pembelajaran dan pertumbuhan, di mana ukuran non keuangan merupakan pendorong bagi kinerja keuangan di masa depan. Balanced Scorecard memiliki empat perspektif, yaitu perspektif keuangan, perspektif pelanggan, perspektif proses bisnis internal, serta perspektif pertumbuhan dan pembelajaran (Kaplan \& Norton, 1996).

Presektif keuangan dalam Balanced Scorecard seharusnya akan mendorong unit bisnis untuk mengaitkan tujuan finansial dengan strategi korporasi. Tujuan finansial menjadi fokus tujuan dan ukuran di semua perspektif scorecard lainnya. Setiap ukuran terpilih harus merupakan bagian dari hubungan sebab akibat yang pada akhirnya akan dapat meningkatkan kinerja keuangan. Bagi sebagian besar perusahaan, tema finansial berupa peningkatan 
pendapatan, penurunan biaya dan peningkatan produktivitas, peningkatan pemanfaatan aktiva, dan penurunan risiko dapat meghasilkan keterkaitan yang diperlukan di antara keempat perspektif scorecard (Kaplan \& Norton, 2005).

Dalam perspektif pelanggan Balanced Scorecard, perusahaan melakukan identifikasi pelanggan dan segmen pasar yang akan dimasuki. Segmen pasar merupakan sumber yang akan menjadi komponen penghasilan tujuan finansial perusahaan. Perspektif pelanggan memungkinkan perusahaan meyelaraskan berbagai ukuran pelanggan penting (kepuasan, loyalitas, retensi, akuisisi, dan profitabilitas) dengan pelanggan dan segmen pasar sasaran (Kaplan \& Norton, 2005). Perspektif pelanggan juga memungkinkan perusahaan melakukan identifikasi dan pengukuran, secara eksplisit, proposisi nilai yang akan perusahaan berikan kepada pelanggan dan pasar sasaran. Dalam perspektif pelanggan Balanced Scorecard, selain keinginan untuk memuaskan dan menyenangkan pelanggan, para manajer unit bisnis juga harus menterjemahkan pernyataan misi dan strategi ke dalam tujuan yang disesuaikan dengan pasar dan pelanggan yang spesifik (Niven, 2002).

Pada perspektif proses bisnis internal, para manajer melakukan identifikasi berbagai proses yang sangat penting untuk mencapai tujuan pelanggan dan pemegang saham. Sebagian besar sistem pengukuran kinerja perusahaan yang ada memfokuskan kepada peningkatan proses operasi saat ini (Kaplan \& Norton, 2001). Dalam Balanced Scorecard, disarankan agar para manajer menentukan rantai nilai internal lengkap yang diawali dengan proses inovasi, mengenali kebutuhan pelanggan saat ini dan yang akan datang serta mengembangkan pemecahan kebutuhan tersebut, dilanjutkan dengan proses operasi, menyampaikan produk dan jasa saat ini kepada pelanggan saat ini, dan diakhiri dengan layanan purna jual yang menawarkan layanan sesudah penjualan, yang memberi nilai tambah kepada produk dan jasa yang diterima pelanggan (Yuwono et al., 2002).

Pada perspektif pembelajaran dan pertumbuhan, Balanced Scorecard mengembangkan tujuan dan ukuran yang mendorong pembelajaran dan pertumbuhan perusahaan. Tujuan di dalam perspektif pembelajaran dan pertumbuhan adalah menyediakan infrastruktur yang memungkinkan untuk mencapai tiga perspektif lainnya (Yuwono et al., 2002). Balanced Scorecard menekankan pentingnya menanamkan investasi bagi masa datang, dan bukan dalam bidang investasi tradisional saja, seperti peralatan baru, riset, dan pengembangan produk baru. Investasi peralatan jelas sangat penting, tetapi tampaknya tidak cukup hanya dengan itu saja. Perusahaan juga harus melakukan investasi dalam infrastruktur para pekerja, sistem dan prosedur, jika ingin mencapai tujuan pertumbuhan keuangan jangka panjang (Kaplan \& Norton, 2007).

Dalam penelitian ini, pengukuran kinerja dengan Balanced Scorecard akan dilakukan dengan data sekunder yang sudah tersedia. Aspek-aspek yang digunakan dalam balanced scorecard, yaitu sebagai berikut:

1. Aspek Keuangan, perspektif keuangan menjadi focus tujuan dan ukuran di semua perspektif lainnya. Setiap ukuran yang terpilih harus merupakan hubungan sebab akibat yang pada akhirnya akan meningkatkan kinerja finansial. Hal pertama yang harus dilakukan 
perusahaan ketika melakukan pengukuran secara finansial adalah mendeteksi keberadaannya dalam industri. Posisi perusahaan dalam industri mempengaruhi strategi perusahaan yang selanjutnya berpengaruh pada penentuan indikator pengukuran finansial perusahaan (Kaplan \& Norton, 2007).

2. Aspek Pelanggan, perspektif pelanggan lebih cenderung terhadap suatu barang atau produk yang umumnya dilatar belakangi oleh empat kategori, yaitu waktu, kualitas, kinerja dan pelayanan, serta biaya. Untuk memenuhi keinginan pelanggan, tantangan selanjutnya yang harus dihadapi perusahaan adalah menerjemahkan keinginan-keinginan dari pelanggan ke dalam proses bisnis internal perusahaan (Kaplan \& Norton, 2005).

3. Aspek Proses Bisnis Intenal, pada perspektif proses bisnis internal, mengidentifikasikan berbagai proses internal yang sangat penting untuk mencapai tujuan pelanggan dan tujuan finansial perusahaan. Proses ini memungkinkan unit bisnis untuk memberikan preposisi nilai yang akan menarik perhatian dan mempertahankan pelanggan dalam segmen pasar sasaran, serta memenuhi harapan keuntungan finansial yang tinggi para pemegang saham (Kaplan \& Norton, 2001).

4. Aspek Pembelajaran dan Pertumbuhan, hal yang mendasari diperlukannya perspektif pembelajaran dan pertumbuhan adalah selalu berubahnya target-target yang ditetapkan oleh perusahaan. Perubahan-perubahan target tersebut tidak lepas dari kondisi dunia bisnis pada era globalisasi yang cenderung sangat dinamis. Oleh karena itu, dengan upaya pembelajaran dan pertumbuhan, perusahaan bisa secara terus menerus menyelaraskan target-targetnya dengan kedinamisan dari pergerakan dunia bisnis. Kemampuan untuk selalu berinovasi, berkembang, dan belajar berpengaruh secara langsung terhadap nilai dari sebuah perusahaan (Kaplan \& Norton, 2007).

Tabel 1. Penilaian Kinerja dengan Metode Balanced Scorecard

\begin{tabular}{lll}
\hline \multicolumn{1}{c}{ Variabel } & \multicolumn{1}{c}{ Dimensi } & \multicolumn{1}{c}{ Indikator } \\
\hline Prespektif & Perspektif keuangan yang & 1. Profil Risiko (risk \\
Keuangan & menggambarkan konsekuensi & profile): NPF dan FDR. \\
& tindakan ekonomi yang & 2. Rentabilitas: ROA, ROE \\
& diambil dalam indikator & dan BOPO. \\
& keuangan. & 3. Permodalan: CAR. \\
Perspektif & Perspektif pelanggan & 1. Pangsa Pasar (Market \\
Pelanggan & mendefinisikan pelanggan dan & Share) \\
& segmen pasar dimana unit & 2. Customer Profitability \\
& usaha akan bersaing. & (Profitabilitas Pelanggan). \\
Perspektif & Perspektif proses bisnis & 1. Inovasi. \\
Proses Bisnis & internal melukiskan proses & 2. Pelayanan purna jual. \\
Interna & internal diperlukan untuk & \\
& memberikan nilai bagi & \\
& pelanggan dan pemilik. &
\end{tabular}


Perspektif Perspektif pembelajaran dan

Pembelajaran pertumbuhan mendefinisikan

dan

Pertumbuhan kapabilitas diperlukan induk

organisasi untuk menciptakan

pertumbuhan jangka panjang

dan perbaikan.
1. Tingkat Retensi Karyawan.

2. Tingkat Produktivitas

Karyawan.

Sumber: Diadopsi dari (Kaplan \& Norton, 2007), (Yuwono et al., 2002), dan (Hery, 2017)

\section{Perspektif Keuangan}

\section{NPF (Non Performing Financing)}

NPF yaitu rasio pembiayaan bermasalah terhadap total pembiayaan. NPF merupakan pembiayaan yang sedang mengalami kemacetan dalam pelunasannya yang terjadi karena faktor yang disengaja ataupun faktor yang tidak disengaja (Rizal \& Humaidi, 2021). Semakin rasio ini menunjukkan kualitas pembiayaan pada bank syariah semakin buruk Rumus untuk menghitung rasio NPF adalah:

$$
\mathrm{NPF}=\frac{\text { Pembiayaan Bermasalah }}{\text { Total Pembiayaan }} \times 100 \%
$$

Tabel 2. Kriteria Penilaian Rasio NPF

\begin{tabular}{lll}
\hline \multicolumn{1}{c}{ Peringkat } & \multicolumn{1}{c}{ Kriteria } & \multicolumn{1}{c}{ Keterangan } \\
\hline Peringkat 1 & $\mathrm{NPF}<2 \%$ & Sangat Baik \\
Peringkat 2 & $2 \% \leq \mathrm{NPF}<5 \%$ & Baik \\
Peringkat 3 & $5 \% \leq \mathrm{NPF}<8 \%$ & Cukup Baik \\
Peringkat 4 & $8 \% \leq \mathrm{NPF}<12 \%$ & Kurang Baik \\
Peringkat 5 & $\mathrm{NPF} \geq 12 \%$ & Tidak Baik \\
\hline
\end{tabular}

Sumber: SE Bank Indonesia No. 13/ 24/ DPNP/2011

\section{FDR (Financing to Deposit Ratio)}

FDR merupakan rasio untuk mengukur komposisi jumlah pembiayaan yang diberikan dibandingkan dengan jumlah dana masyarakat atau dana pihak ketiga yang digunakan. Rasio ini menunjukkan kesehatan bank dalam memberikan pembiayaan.

$$
\mathrm{FDR}=\frac{\text { Total Pembiayaan }}{\text { Dana Pihak Ketiga }} \times 100 \%
$$

Tabel 3. Kriteria Penilaian Rasio FDR

\begin{tabular}{ccc}
\hline Peringkat & Kriteria & Keterangan \\
\hline Peringkat 1 & $50 \%<$ FDR $\leq 75 \%$ & Sangat Baik \\
Peringkat 2 & $75 \%<$ FDR $\leq 85 \%$ & Baik \\
Peringkat 3 & $85 \%<$ FDR $\leq 100 \%$ atau & Cukup Baik \\
& FDR $\leq 50 \%$ & \\
Peringkat 4 & $100 \%<$ FDR $\leq 120 \%$ & Kurang Baik \\
Peringkat 5 & FDR $>120 \%$ & Tidak Baik \\
\hline \multicolumn{2}{l}{ Sumber: SE Bank Indonesia No. 13/ 24/ DPNP/2011 }
\end{tabular}


3. ROA (Return on Asset)

ROA rasio untuk mengukur kemampuan bank dalam mengelola dana yang diinvestasikan dalam keseluruhan aktiva yang menghasilkan keuntungan dan menggambarkan produktivitas bank dalam mengelola dana. Semakin besar rasio ROA suatu bank, maka semakin besar pula tingkat keuntungan yang dicapai bank dan semakin baik kemampuan manajemen bank dalam mengelola aktiva. Rumus ROA :

$$
\text { ROA }=\frac{\text { Laba Sebelum Pajak }}{\text { Total Aset }} \times 100 \%
$$

Tabel 4. Kriteria Penilaian Rasio ROA

\begin{tabular}{cll}
\hline Peringkat & \multicolumn{1}{c}{ Kriteria } & \multicolumn{1}{c}{ Keterangan } \\
\hline Peringkat 1 & $\mathrm{ROA}>2 \%$ & Sangat Baik \\
Peringkat 2 & $1.25 \%<\mathrm{ROA} \leq 1.5 \%$ & Baik \\
Peringkat 3 & $0.5 \%<\mathrm{ROA} \leq 1.25 \%$ & Cukup Baik \\
Peringkat 4 & $0 \%<\mathrm{ROA} \leq 0.5 \%$ & Kurang Baik \\
Peringkat 5 & $\mathrm{ROA} \leq 0 \%$ & Tidak Baik \\
\hline Sumber: SE Bank Indonesia No. 13/ 24/ DPNP/2011
\end{tabular}

\section{ROE (Return on Equity)}

Rasio ROE untuk mengukur kemampuan bank dalam memperoleh laba bersih yang dikaitkan dengan pembayaran deviden. Semakin besar rasio ini menunjukkan kemampuan modal disetor bank dalam menghasilkan laba pemegang saham semakin besar, rumusnya :

$$
\mathrm{ROE}=\frac{\text { Laba Bersih }}{\text { Total Ekuitas }} \times 100 \%
$$

Tabel 5. Kriteria Penilaian Rasio ROE

\begin{tabular}{cll}
\hline \multicolumn{1}{c}{ Peringkat } & \multicolumn{1}{c}{ Kriteria } & \multicolumn{1}{c}{ Keterangan } \\
\hline Peringkat 1 & $\mathrm{ROE} \geq 50 \%$ & Sangat Baik \\
Peringkat 2 & $35 \% \leq \mathrm{ROE}<50 \%$ & Baik \\
Peringkat 3 & $20 \% \leq \mathrm{ROE}<35 \%$ & Cukup Baik \\
Peringkat 4 & $5 \% \leq \mathrm{ROE}<20 \%$ & Kurang Baik \\
Peringkat 5 & $\mathrm{ROE}<5 \%$ & Tidak Baik \\
\hline \multicolumn{2}{l}{ Sumber: SE Bank Indonesia No. 13/ 24/ DPNP/2011 }
\end{tabular}

5. BOPO (Beban Operasional dan Pendapatan Operasional)

Rasio BOPO adalah perbandingan antara biaya operasional dengan pendapatan operasional. Tujuannya mengukur efesiensi kegiatan operasional bank syariah. Semakin kecil rasio biaya operasionalnya akan lebih baik, karena biaya yang dikeluarkan lebih kecil dibandingkan pendapatan yang diterima, rumusnya adalah: 


$$
\text { BOPO }=\frac{\text { Biaya Operasional }}{\text { Pendapatan Operasional }} \times 100 \%
$$

Tabel 6. Kriteria Penilaian Rasio BOPO

\begin{tabular}{ccc}
\hline Peringkat & Kriteria & Keterangan \\
\hline Peringkat 1 & BOPO $\leq 83 \%$ & Sangat Baik \\
Peringkat 2 & $83 \%<$ BOPO $\leq 85 \%$ & Baik \\
Peringkat 3 & $85 \%<$ BOPO $\leq 87 \%$ & Cukup Baik \\
Peringkat 4 & $87 \%<$ BOPO $\leq 89 \%$ & Kurang Baik \\
Peringkat 5 & BOPO $>89 \%$ & Tidak Baik \\
\hline \multicolumn{2}{c}{ Sumber: SE Bank Indonesia No. 13/24/ DPNP/2011 }
\end{tabular}

\section{CAR (Capital Adequacy Ratio)}

Rasio CAR untuk mengukur kecukupan modal bank dalam menyerap kerugian dan pemenuhan ketentuan KPMM (Kewajiban Penyedian Modal Minimum). Hal yang perlu diperhatikan dalam rasio ini adalah mengetahui besarnya estimasi risiko yang akan terjadi dalam pemberian kredit atau risiko yang ditimbulkan pada pemberian pembiayaan, rumus rasio CAR :

$$
\mathrm{CAR}=\frac{\text { Modal }}{\text { Aset Tertimbang Menurut Risiko }} \times 100 \%
$$

Tabel 7. Kriteria Penilaian Rasio CAR

\begin{tabular}{lll}
\hline \multicolumn{1}{c}{ Peringkat } & \multicolumn{1}{c}{ Kriteria } & \multicolumn{1}{c}{ Keterangan } \\
\hline Peringkat 1 & CAR $\geq 12 \%$ & Sangat Baik \\
Peringkat 2 & $9 \% \leq$ CAR $<12 \%$ & Baik \\
Peringkat 3 & $8 \% \leq$ CAR $<9 \%$ & Cukup Baik \\
Peringkat 4 & $6 \%<$ CAR $<8 \%$ & Kurang Baik \\
Peringkat 5 & KPMM $\leq 6 \%$ & Tidak Baik \\
\hline \multicolumn{2}{c}{ Sumber: SE Bank Indonesia No. 13/ 24/ DPNP/2011 }
\end{tabular}

\section{Perspektif Pelanggan}

1. Pangsa Pasar (Market Share) untuk mengukur besarnya penguasaan pasar oleh produk yang disebar/ditawarkan oleh organisasi. Apabila nilai yang didapat semakin tinggi, hal ini akan menunjukkan bahwa organisasi mampu menguasai segmen pasar produk/jasa (Koesomowidjojo, 2017). Rumus Market Share :

$$
\text { Market Share }=\frac{\text { Aset }}{\text { Aset Organisasi Secara Nasional }} \times 100 \%
$$

2. Customer Profitability (Profitabilitas Pelanggan) untuk mengukur besarnya keuntungan yang dapat diraih dari pendapatan penjualan produk/penawaran jasa yang diberikan kepada konsumen. Semakin banyak pelanggan puas dalam membeli produk dan menggunakan jasa organisasi tersebut, akan semakin banyak keuntungan yang didapat oleh organisasi (Koesomowidjojo, 2017). Rumus Profitabilitas Pelanggan : 


$$
\text { Profitabilitas Konsumen }=\frac{\text { Total Pembiayaan Konsumen }}{\text { Total Laba Usaha }}
$$

\section{Perspektif Proses Bisnis Internal}

1. Proses Inovasi untuk mengukur Kemampuan manajer dalam mengidentifikasi pasar dan menciptakan produk/jasa untuk memenuhi kebutuhan pasar adalah kekuatan kunci bagi perusahaan (Ulum, 2017). Indikator ini diukur oleh peneliti dengan menganalisa perkembangan produk-produk Bank Mega Syariah dari tahun 2015-2019.

2. Pelayanan Purna Jual untuk meningkatkan daya saing perusahaan yang harus diperhatikan guna merancang strategi bisnis perusahaan untuk memenangkan persaingan, di samping keunggulan pada harga atau biaya, kualitas, pengiriman, fleksibilitas, dan desain produk/jasa. Perusahaan dapat mengukur apakah upayanya dalam pelayanan purna jual ini telah memenuhi harapan pelanggan, dengan menggunakan pengukuran waktu dari saat keluhan pelanggan diterima hingga keluhan itu diselesaikan (Ulum, 2017). Rumus layanan purna jual :

$$
\text { Layanan Purna Jual }=\frac{\text { Jumlah Keluhan Pelanggan }}{\text { Jumlah Keluahan yang ditangani }} \times 100 \%
$$

\section{Perspektif Pembelajaran dan Pertumbuhan}

1. Tingkat Retensi Karyawan untuk mengukur kemampuan perusahaan mempertahankan karyawan terbaiknya. Semakin sedikit karyawan yang keluar (masuk) maka akan semakin baik bagi perusahaan karena hal ini menunjukkan perusahaan mampu mempertahankan karyawan dan mengelola SDM dengan baik (Saraswati, 2017). Rumus retensi karyawan :

$$
\text { Retensi Karyawan }=\frac{\text { Jumlah Karyawan yang Keluar }}{\text { Jumlah Karyawan }} \times 100 \%
$$

2. Tingkat produktivitas karyawan akan sangat berpengaruh pada pertumbuhan organisasi. Perspektif pertumbuhan dan pembelajaran yang memfokuskan pada sumber daya manusia akan menganalisis bagaimana dampak usaha peningkatan moral, kondisi lingkungan kerja, keahlian karyawan, inovasi, proses internal, dan kepuasan konsumen. Tingkat produktivitas karyawan untuk mengukur pertumbuhan dan perkembangan organisasi. Semakin tinggi tingkat produktivitas karyawan, berarti menunjukkan semakin tinggi output yang dihasilkan oleh masing-masing karyawan (Umar, 2004). Rumus produktivitas karyawan:

$$
\text { Produktivitas Tenaga Kerja }=\frac{\text { Produktivitas Jumlah Produksi (Laba Operasi) }}{\text { Jumlah Tenaga Kerja }}
$$




\section{METODE PENELITIAN}

Jenis penelitian yang digunakan adalah kuantitif deskriptif. Dalam Penelitian ini penulis menggunakan mendeskripsikan hasil temuan kinerja Bank Mega Syariah dari empat (4) prespektif. Tujuannya untuk mengetahui kinerja perusahaan dengan 4 perspektif dengan konsep Balanced Scorecard yaitu perspektif keuangan, perpektif pelanggan, perspektif proses bisnis internal, dan perspektif pembelajaran dan pertumbuhan pada Bank Mega Syariah Tahun 2015-2019. Sumber data yaitu data sekunder, yang diperoleh dari Laporan Keuangan dan Laporan Tahunan yang telah dipublikasi oleh Bank Mega Syariah. Teknik pengumpulan data menggunakan metode dokumentasi dari website resmi Otoritas Jasa Keuangan, Laporan Keuangan Bank Mega Syariah, serta Annual Report Bank Mega Syariah. Teknik analisis data yaitu dengan menghitung skor masing-masing perspektif, berdasarkan kriteria yang telah ditetapkan

\section{HASIL DAN PEMBAHASAN}

\section{Penilaian Kinerja pada Aspek Keuangan}

Hasil olah data sekunder dari Laporan Keuangan Bank Mega Syariah, menunjukkan nilai risiko pembiayaan atan Non Performing Financing (NPF) pada lima tahun terakhir secara keseluruhan menunjukkan total rata-rata NPF Bank Mega Syariah periode tahun 2015 hingga 2019 sebesar 2,88\% dengan predikat sehat (Bank Mega Syariah, 2019). Pada tahun 2015 hingga 2019 terjadi penurunan nilai rasio NPF Bank Mega Syariah secara berturut-turut, yang menunjukkan bahwa kinerja non performing financing Bank Mega Syariah yang semakin baik. Hal ini juga menunjukkan bahwa Bank Mega Syariah memiliki kemampuan pengelolaan pembiayaan bermasalah yang sangat baik.

Hasil olah data sekunder dari Laporan Keuangan Bank Mega Syariah, pada rasio Financing to Deposit Ratio (FDR) menunjukkan total rata-rata rasio keseluruhan selama tahun 2015-2019 yakni sebesar 94,04\% dengan predikat cukup sehat (Bank Mega Syariah, 2019). Hal ini menunjukkan bahwa bank memiliki kemampuan pengelolaan likuiditas yang cukup baik, sehingga berisiko cukup rendah bank mengalami kegagalan dalam membayar kewajiban jangka pendeknya.

Penilaian yang ditinjau dari aspek rentabilitas menggunakan rasio Return on Asset (ROA) secara keseluruhan nilai rasio ROA Bank Mega Syariah menunjukkan rata-rata sebesar 1,26\% yang artinya Bank Mega Syariah dalam periode tahun 2015 hingga 2019 berada dalam kategori sehat (Bank Mega Syariah, 2019). Dengan memperoleh predikat sehat tersebut, laba melebihi target dan mendukung pertumbuhan permodalan bank yang artinya bahwa kinerja bank mega syariah dalam menghasilkan laba memadai, dan kemampuan laba dalam meningkatkan permodalan dan prospek laba di masa datang tinggi.

Penilaian pada rasio Return on Equity (ROE) Bank Mega Syariah pada tahun 2015-2019 memiliki nilai rata-rata sebesar 5,74\% dengan mendapat predikat cukup sehat (Bank Mega Syariah, 2019a). Hal ini menandakan bahwa rentabilitas cukup memadai, laba memenuhi 
target, namun terdapat tekanan terhadap kinerja laba yang dapat menyebabkan penurunan laba namun cukup dapat mendukung pertumbuhan permodalan bank.

Hasil olah data sekunder dari Laporan Keuangan Bank Mega Syariah, menunjukkan bahwa nilai rata-rata rasio BOPO Bank Mega Syariah tahun 2015-2019 berada pada peringkat komposit 1 dengan nilai rasio 92,88\% (Bank Mega Syariah, 2019a), yang artinya beban operasional dan pendapatan operasional Bank Mega Syariah dalam keadaan sangat sehat.

Pada nilai rata-rata keseluruhan rasio Capital Adequacy Ratio (CAR) Bank Mega Syariah pada tahun 2015-2019 diperoleh nilai rasio CAR sebesar 20,99\% dengan predikat sangat sehat (PK-1) (Bank Mega Syariah, 2019), hal ini menandakan bahwa bank memiliki kualitas dan kecukupan permodalan yang sangat memadai relatif terhadap profil risikonya, yang disertai dengan pengelolaan permodalan yang sangat kuat sesuai dengan karakteristik, skala usaha, dan kompleksitas usaha Bank.

\section{Penilaian Kinerja pada Aspek Pelanggan}

Pada Tabel 8 dibawah ini, menunjukkan pangsa pasar tersebut dapat di lihat bahwa terjadi penurunan nilai rasio pangsa pasar yang lebih dominan pada tahun 2015-2109, menunjukkan bahwa Bank Mega Syariah belum mampu menguasai segmen pasar produk/jasa yang artinya nilai rasio pangsa dalam tiap tahunnya tidak dalam kritetia semakin tinggi, namun terjadi tingkat penurunan yang lebih dominan dibandingkan peningkatannya. Karena, apabila nilai pangsa pasar yang didapat semakin tinggi, hal ini akan menunjukkan bahwa organisasi mampu menguasai segmen pasar produk/jasa (Koesomowidjojo, 2017).

Tabel 8. Pangsa Pasar (Market Share) Bank Mega Syariah 2015-2019 (Dalam miliar rupiah)

\begin{tabular}{cllc}
\hline Tahun & $\begin{array}{c}\text { Aset Bank Mega } \\
\text { Syariah }\end{array}$ & $\begin{array}{c}\text { Aset Organisasi } \\
\text { secara Nasional }\end{array}$ & $\begin{array}{c}\text { Pangsa Pasar } \\
\text { (Market Share) }\end{array}$ \\
\hline 2015 & 5.560 & 213.423 & $2,61 \%$ \\
2016 & 6.135 & 254.184 & $2,41 \%$ \\
2017 & 7.034 & 288.027 & $2,44 \%$ \\
2018 & 7.336 & 316.691 & $2,32 \%$ \\
2019 & 8.008 & 350.364 & $2,29 \%$ \\
\hline
\end{tabular}

Sumber: Data Sekunder yang diolah, 2020. (Bank Mega Syariah, 2019)

Pada Tabel 9, dibawah ini menunjukkan profitabilitas pelanggan Bank Mega Syariah, dapat dilihat bahwa terjadi peningkatan yang lebih dominan dikarenakan pelanggan puas atas produk yang didapatnya, sehingga mengarahkan organisasi dalam mendapatkan keuntungan. Semakin banyak pelanggan puas dalam membeli produk dan menggunakan jasa organisasi tersebut, akan semakin banyak keuntungan yang didapat oleh organisasi (Koesomowidjojo, 2017). Dengan terjadinya peningkatan profitabilitas pelanggan yang lebih dominan pada tahun 2015-2019 tersebut menunjukkan bahwa kinerja Bank Mega Syariah dalam mendapatkan keuntungan dari pelanggan semakin baik. 
Tabel 9. Profitabilitas Pelanggan Bank Mega Syariah 2015-2019

(Dalam jutaan rupiah)

\begin{tabular}{cccc}
\hline Tahun & Pembiayaan Konsumen & Laba Usaha & $\begin{array}{c}\text { Profitabilitas } \\
\text { Pelanggan }\end{array}$ \\
\hline 2015 & 4.211 .473 & 6.760 & 623 \\
2016 & 4.714 .812 & 137.775 & 34 \\
2017 & 4.641 .539 & 91.043 & 51 \\
2018 & 5.178 .619 & 50.513 & 103 \\
2019 & 6.080 .453 & 57.925 & 105 \\
\hline
\end{tabular}

Sumber: Data Sekunder yang diolah, 2020. (Bank Mega Syariah, 2019)

\section{Penilaian Kinerja pada Aspek Proses Bisnis Internal}

Pada proses inovasi dalam setiap tahunnya Bank Mega Syariah telah meningkatkan inovasi dari tahun 2015 hingga tahun 2019. Di mana pada tahun 2015, Bank Mega Syariah meningkatkan kualitas produk serta menjalankan program pemasaran yang bertujuan untuk meningkatkan volume dana khususnya dari segmen ritel dan mempercepat pertumbuhan customer based. Tahun 2016, Bank Mega Syariah telah menunjukkan kinerja peningkatan layanan dan Corporate Image: Penempatan 7 (tujuh) ATM. Tahun 2017, Bank Mega Syariah meningkatkan layanan kepada nasabahnya dengan meluncurkan Program dan Aktivitas Baru, di antaranya yaitu, Program Diskon Debit Card. Pada tahun 2018, Bank Mega Syariah (BMS) telah mempromosikan dan mensosialisasikan produk dan program melalui media berikut: Iklan pada Media TV Nasional untuk Program Diskon Debet Transmart dan Merchant CT Corp, Iklan pada Website Resmi Perusahaan untuk seluruh produk dan program-program terbaru. Kemudian pada tahun 2019, BMS melakukan re-launch Mobile Banking dengan menggunakan design baru dengan beberapa tambahan fitur terutama untuk pembayaran Zakat, Infaq dan Sodaqoh.

Tabel 10. Kinerja Bank Mega Syariah dalam Pelayanan Purna Jual

\begin{tabular}{cccccc}
\hline Tahun & $\begin{array}{c}\text { Jumlah keluhan } \\
\text { pelanggan }\end{array}$ & $\begin{array}{c}\text { Jumlah keluhan } \\
\text { yang ditangani }\end{array}$ & $\begin{array}{c}\text { Layanan Purna } \\
\text { Jual }\end{array}$ & Penilaian & Kriteria \\
\hline 2015 & 13 & 13 & $100 \%$ & Telah diselesaikan & Baik \\
2016 & 3920 & 3920 & $100 \%$ & Telah diselesaikan & Baik \\
2017 & 4542 & 4542 & $100 \%$ & Telah diselesaikan & Baik \\
2018 & 5523 & 5523 & $100 \%$ & Telah diselesaikan & Baik \\
2019 & 6178 & 6178 & $100 \%$ & Telah diselesaikan & Baik \\
\hline
\end{tabular}

Sumber: Data Sekunder yang diolah, 2020 (Bank Mega Syariah, 2019)

Tabel 10 diatas menunjukkan pelayanan purna jual Bank Mega Syariah, dapat dilihat bahwa tahun 2015 sampai dengan tahun 2019 Bank Mega Syariah mengalami peningkatan keluhan pelanggan secara berturut-turut dari tahun 2015-2019. Peningkatan keluhan pelanggan tersebut telah ditangani/diselesaikan oleh Bank Mega Syariah di setiap tahunnya. Perusahaan yang dapat mengukur apakah upayanya dalam pelayanan purna jual ini telah memenuhi harapan pelanggan, yaitu dengan menggunakan pengukuran waktu dari saat 
keluhan pelanggan diterima hingga keluhan itu diselesaikan (Warindrani, 2017). Karena Bank Mega Syariah pada tahun 2015-2019 telah menyelesaikan keluhan pelanggan dengan baik, maka dapat diartikan bahwa layanan purna jual Bank Mega Syariah dapat meningkatkan daya saing perusahaan guna merancang strategi bisnis perusahaan untuk memenangkan persaingan, di samping keunggulan pada harga/biaya, kualitas, pengiriman, fleksibilitas, dan desain produk/jasa.

\section{Penilaian Kinerja pada Aspek Pembelajaran dan Pertumbuhan}

Pada Tabel 11 dibawah ini, dapat dilihat bahwa terjadi penurunan nilai rasio retensi karyawan Bank Mega Syariah pada tahun 2015-2019 secara berturut-turut. Penurunan rasio retensi karyawan yang secara berturut-turut tersebut menunjukkan bahwa Bank Mega Syariah memiliki kemampuan dalam mempertahankan karyawan terbaiknya, karena semakin sedikit karyawan yang keluar (masuk) maka akan semakin baik bagi perusahaan karena hal ini menunjukkan perusahaan mampu mempertahankan karyawan dan mengelola SDM dengan baik (Kaplan \& Norton, 2007).

Tabel 11. Hasil Tingkat Retensi Karyawan Bank Mega Syariah

\begin{tabular}{cccc}
\hline Tahun & $\begin{array}{c}\text { Jumlah Karyawan } \\
\text { yang Keluar }\end{array}$ & $\begin{array}{c}\text { Jumlah } \\
\text { Karyawan }\end{array}$ & $\begin{array}{c}\text { Retensi } \\
\text { Karyawan }\end{array}$ \\
\hline 2015 & 2.451 & 2.316 & $105,83 \%$ \\
2016 & 885 & 1.431 & $61,85 \%$ \\
2017 & 150 & 1.281 & $11,71 \%$ \\
2018 & 108 & 1.173 & $9,21 \%$ \\
2019 & 44 & 1.129 & $3,90 \%$ \\
\hline
\end{tabular}

Sumber: Data Sekunder yang diolah, 2020. (Bank Mega Syariah, 2019)

Pada Tabel 12 dibawah ini, menunjukkan bahwa produktivitas karyawan Bank Mega Syariah, dapat dilihat bahwa terjadi peningkatan dengan jumlah produktivitas karyawan yang lebih dominan. Sehingga dapat diartikan bahwa kinerja Bank Mega Syariah dapat meningkatkan produktivitas karyawan dan dapat mendongkrak pertumbuhan dan perkembangan organisasi. Karena, semakin tinggi tingkat produktivitas karyawan, berarti menunjukkan semakin tinggi output yang dihasilkan oleh masing-masing karyawan (Devani, 2016).

Tabel 12. Hasil Tingkat Produktivitas Karyawan Bank Mega Syariah

\begin{tabular}{cccc}
\hline Tahun & Laba Operasi & Jumlah Tenaga Kerja & $\begin{array}{c}\text { Produktivitas Karyawan } \\
\text { (dalam jutaan rupiah) }\end{array}$ \\
\hline 2015 & 6.760 & 2.316 Pegawai & 2,92 \\
2016 & 137.775 & 1.431 Pegawai & 96,28 \\
2017 & 91.043 & 1.281 Pegawai & 71,07 \\
2018 & 50.513 & 1.173 Pegawai & 43,06 \\
2019 & 57.925 & 1.129 Pegawai & 51,31 \\
\hline
\end{tabular}


Sumber: Data Sekunder yang diolah, 2020. (Bank Mega Syariah, 2019) (Bank Mega Syariah, 2019)

\section{KESIMPULAN}

Penilaian kinerja Bank Mega Syariah dengan metode Balanced Scorecard untuk perspektif keuangan periode tahun 2015-2019, dengan menggunakan rasio NPF menunjukkan total rata-rata sebesar $2,88 \%$ dengan predikat sehat. Pada rasio FDR menunjukkan total ratarata sebesar $94,04 \%$ dengan predikat cukup sehat. Pada rasio ROA menunjukkan total rata-rata sebesar $1,26 \%$ dengan predikat sehat. Pada rasio ROE menunjukkan total rata-rata sebesar $5,74 \%$ dengan predikat cukup sehat. Pada rasio BOPO menunjukkan total rata-rata sebesar $92,88 \%$ dengan predikat sangat sehat. Pada rasio CAR menunjukkan total rata-rata sebesar 20,99\% dengan predikat sangat sehat.

Penilaian kinerja Bank Mega Syariah dengan metode Balanced Scorecard untuk perspektif pelanggan periode tahun 2015-2019, dengan menggunakan rasio Pangsa Pasar terjadi penurunan yang menunjukkan bahwa Bank Mega Syariah belum mampu menguasai segmen pasar produk/jasa. Kemudian untuk anlaisis pada Profitabilitas Pelanggan terjadi peningkatan yang menunjukkan bahwa kinerja Bank Mega Syariah dalam mendapatkan keuntungan dari pelanggan semakin baik.

Penilaian kinerja Bank Mega Syariah dengan metode Balanced Scorecard untuk perspektif proses bisnis internal periode tahun 2015-2019, dengan menggunakan analisis Proses Inovasi terjadi peningkatan yang menunjukkan bahwa kinerja Bank Mega Syariah (BMS) memiliki kemampuan dalam mengidentifikasi pasar dan menciptakan produk/jasa. Kemudian untuk analisis Pelayanan Purna Jual terjadi peningkatan keluhan pelanggan yang telah diselesaikan pada tiap tahunnya, yang menunjukkan bahwa BMS dapat meningkatkan daya saing perusahaan.

Penilaian kinerja Bank Mega Syariah dengan metode Balanced Scorecard untuk perspektif pembelajaran dan pertumbuhan periode tahun 2015-2019, dengan menggunakan rasio tingkat retensi karyawan terjadi penurunan secara berturut-turut menunjukkan bahwa Bank Mega Syariah memiliki kemampuan dalam mempertahankan karyawan terbaiknya. Kemudian untuk analisis tingkat produktivitas karyawan terjadi peningkatan dengan jumlah produktivitas karyawan yang cukup besar menunjukkan bahwa kinerja Bank Mega Syariah dapat meningkatkan produktivitas karyawan dan dapat mendongkrak pertumbuhan dan perkembangan organisasi.

\section{REFERENSI}

Bank Indonesia. (2011). SE Bank Indonesia No. 13/24/ DPNP/2011 (Vol. 2009, Issue 13).

Bank Mega Syariah. (2016). Annual Report 2016.

Bank Mega Syariah. (2017). Annual Report 2017. http://www.paindubaisyariah.co.id/. diakses pada 26 Maret 2019

Bank Mega Syariah. (2018). Annual Report 2018. 
Bank Mega Syariah. (2019a). Annual Report 2019. 1-727.

Bank Mega Syariah. (2019b). Laporan Keluhan Nasabah 2019 (Issue 1).

Bank Mega Syariah. (2019c). Laporan Keuangan Desember 2019. Laporan Posisi Keuangan, 1(021), 2985.

Devani, V. (2016). Pengukuran Kinerja Perusahaan dengan Menggunakan Metoda Balanced Scorecard. Jurnal Sains, Teknologi Dan Industri, 13(1), 83-90.

Hery, S. E. (2017). Balanced Scorecard for Business. Gramedia Widiasarana Indonesia.

Ikatan Bankir Indonesia. (2014). Mengelola Bank Komersial. Gramedia Pustaka Utama.

Kaplan, R. S., \& Norton, D. P. (1996). Using the balanced scorecard as a strategic management system.

Kaplan, R. S., \& Norton, D. P. (2001). The strategy-focused organization. Strategy and Leadership, 29(3), 41-42.

Kaplan, R. S., \& Norton, D. P. (2005). The balanced scorecard: measures that drive performance. Harvard Business Review, 83(7), 172.

Kaplan, R. S., \& Norton, D. P. (2007). Balanced scorecard. In Das Summa Summarum des Management (pp. 137-148). Springer.

Koesomowidjojo, S. R. M. (2017). Balance scorecard. Raih Asa sukses.

Marselia, T., Katili, P. B., \& Wahyuni, N. (2017). Pengukuran Kinerja Perusahaan Menggunakan Metode Balanced Scorecard di PDAM Tirta Al-Bantani Kabupaten Serang. Jurnal Teknik Industri Untirta.

Niven, P. R. (2002). Balanced scorecard step-by-step: Maximizing performance and maintaining results. John Wiley \& Sons.

Pratiwi, A. (2015). Perbandingan Kinerja Perusahaan Dengan Pendekatan Balanced Scorecard Pada BPR Syariah. Afkaruna: Indonesian Interdisciplinary Journal of Islamic Studies, 11(1), 96-124.

Putri, N. K., \& Hasanah, U. (2014). Evaluasi Kinerja Perbankan Dengan Perspektif Balanced Scorecard: Studi Pada Perbankan Syariah Di Wilayah Purwokerto. Jurnal Studi Manajemen Dan Bisnis, 1(2), 37-51.

Rizal, F., \& Humaidi, M. (2021). Analisis Tingkat Kesehatan Bank Syariah di Indonesia 20152020. Etihad: Journal of Islamic Banking and Finance, 1(1), 12-22.

Saraswati, A. (2017). Step by Step Lancar Membuat KPI. Penerbit Genesis Learning.

Surat Edaran OJK. (2017). SEOJK NO 14/SEOJK.03/2017 tentang Tingkat Kesehatan BU.

Ulum, I. (2017). INTELLECTUAL CAPITAL: Model Pengukuran, Framework Pengungkapan\& Kinerja Organisasi. UMMPress.

Umar, H. (2004). Riset sumber daya manusia dalam organisasi. Gramedia Pustaka Utama.

Warindrani, A. K. (2017). Akuntansi manajemen. Graha Ilmu.

Yuwono, S., Sukarno, E., \& Ichsan, M. (2002). Petunjuk Praktis Penyusunan Balanced Scorecard: Menuju Organisasi Yang Berfokus Pada Strategi. In Penerbit PT Gramedia Pustaka Utama, Jakarta. 